\title{
IMPLEMENTASI SUPERVISI AKADEMIK UNTUK MENINGKATKAN MUTU GURU
}

Erfy Melany Lalupanda

Universitas Kristen Wira Wacana Sumba

Jl. R. Suprapto No. 35, Waingapu, Prailiu, Sumba Timur, Nusa Tenggara Timur, Indonesia erfylalupanda@gmail.com

\begin{abstract}
Abstrak
Tujuan penelitian ini untuk meningkatkan mutu pembelajaran dan mutu guru melalui implementasi supervisi akademik. Metode penelitian yang digunakan adalah Penelitian Tindakan Sekolah (PTS) dengan pendekatan deskriptif kuantitatif. Teknik pengumpulan data dengan wawancara, studi dokumen dan observasi. Hasil penelitian menunjukkan bahwa supervisi akademik pada siklus 1 dan siklus 2 menunjukkan terjadi peningkatan skor pada aspek perencanaan dan pelaksanaan pembelajaran. Meskipun masih berada pada kategori cukup, namun dari pra siklus sampai dengan siklus 2 terus mengalami peningkatan. Hasil ini dapat dicapai karena adanya kerjasama yang baik antar Kepala Sekolah dan Guru yang disupervisi. Kepala Sekolah berdiskusi dengan guru mengenai masalah yang dihadapi guru pada proses perencanaan dan pelaksanaan pembelajaran. Supervisi akademik yang dilakukan Kepala Sekolah merupakan usaha untuk memperbaiki pengajaran, termasuk menstimulasi, menyeleksi pertumbuhan jabatan dan perkembangan guru- guru serta merevisi tujuan-tujuan pembelajaran, bahan pengajaran, metode, evaluasi atau penilaian pengajaran. Supervisi akademik dapat membantu guru untuk mempelajari dan memahami tugas dan perannya sebagai seorang pendidik.
\end{abstract}

Kata kunci: supervisi akademik, mutu guru

\section{IMPLEMENTATION OF ACADEMIC SUPERVISION FOR INCREASING THE QUALITY OF TEACHERS}

\begin{abstract}
The aim of this study is to improve the quality learning of teachers through the implementation of academic supervision. The research method used is School Action Research (PTS) with a quantitative descriptive approach. Data collection techniques with interviews, document studies, and observations. The results showed that academic supervision in cycle 1 and cycle 2 showed an increase in scores on aspects of planning and implementing learning. Although it is still in a sufficient category, from precycle to cycle 2 it continues to increase. This result can be achieved because of the good cooperation between the Principal and the supervised Teacher. Principals discuss with teachers about the problems faced by teachers in the planning and implementation of learning processes. Academic supervision by the Principal is an effort to improve teaching, including stimulating, selecting the growth of positions and the development of teachers and revising learning objectives, teaching materials, methods, evaluation and evaluation of teaching. Academic supervision can help teachers to learn and understand the task and its role as an educator.
\end{abstract}

Keywords: academic supervision, quality of teachers

Permalink/DOI: http://dx.doi.org10.21831/amp.v7i1.22276 


\section{Pendahuluan}

Penyelenggaraan pendidikan di sekolah sangat menentukan mutu pendidikan. Mutu pendidikan berbicara tentang hasil dan proses yang dilalui untuk memperoleh hasil tersebut. Hasil dari kemampuan sekolah dalam menghasilkan peserta didik yang berprestasi dan menghasilkan lulusan-lulusan terbaik dapat meningkatkan mutu pendidikan. Mutu pembelajaran merupakan salah satu faktor yang menentukan mutu pendidikan.

Mutu pembelajaran merupakan salah satu hasil dari eksistensi seorang guru. Dewasa ini, peran seorang guru tidak sekadar hadir untuk menyampaikan pelajaran dan kemudian kembali ke ruangan melaksanakan kegiatan administrasi atau kegiatan lain. Namun, para guru diharapkan untuk mengambil peran yang lebih luas dari sebelumnya

Kinerja guru adalah manifestasi dari kemampuan guru untuk merencanakan, mengimplementasikan atau melaksanakan, dan menilai hasil belajar siswa. Kinerja guru berkaitan dengan kualitas, kuantitas keuaran, dan keandalan yang dimiliki guru dalam melaksanakan tugasnya. Guru yang memiliki kinerja tinggi dapat meningkatkan kualitas pendidikan. Kinerja guru adalah salah satu faktor utama yang menentukan keberhasilan proses pendidikan di sekolah (Shabir, 2015, pp. 222-224). Kinerja seorang guru akan menentukan kualitas yang dimiliki oleh guru yang bersangkutan. Kualitas guru adalah variabel penting yang akan mempengaruhi kualitas pendidikan, di mana kualitas pendidikan ditunjukkan oleh prestasi siswa (Elliott, 2015, p. 102). Guru memiliki peran yang luar biasa dalam dunia pendidikan. Rendahnya kualitas pendidikan di suatu negara ditentukan oleh kinerja para guru. Guru yang memiliki kinerja tinggi akan menghasilkan lulusan yang berkualitas tinggi.

Mutu guru merupakan bagian penting dari proses pembelajaran. Kemampuan guru dalam melaksanakan pembelajaran diharapakan mampu meningkatkan kualitas kelulusan, baik dalam kualitas pribadi, moral, pengetahuan mampu kompetensi kerja.
Guru harus berkualitas menurut standar tertentu. Kualitas guru yang efektif adalah guru yang mampu membawa peserta didik dengan berhasil mencapai tujuan pembelajaran (Ungin, 2013).

Kinerja dan kualitas guru dinilai melalui suatu kegiatan yang disebut supervisi akademik. Salah satu faktor yang melaksanakan supervisi akademik adalah Kepala Sekolah. Peraturan Menteri Pendidikan Nasional Nomor 13 Tahun 2007 tentang Standar Kepala Sekolah/madrasah (Menteri Pendidikan Nasional Republik Indonesia, 2007) menyatakan bahwa seorang Kepala Sekolah harus memiliki lima dimensi kompetensi minimal yaitu, kompetensi kepribadian, manajerial, kewirausahaan, supervisi dan sosial.

Inti dari dimensi supervisi akademik adalah dalam rangka membina guru untuk meningkatkan mutu proses pembelajaran. Sasaran supervisi akademik pelaksanan proses pembelajaran, yang terdiri dari materi pokok dalam proses pembelajaran, penyusunan silabus dan RPP, pemilihan strategi/metode/teknik pembelajaran, penggunaan media danteknologi informasi dalam pembelajaran, menilai proses dan hasil pembelajaran serta penelitian tindakan kelas (Direktorat Tenaga Kependidikan, 2010).

Menurut Putri \& Wibowo (2018, p. 56) kepala sekolah harus melaksanakan tugas pokok dan fungsinya sebagai manajer atau pengelolah di sekolah dalam meningkatkan proses pembelajaran dan supervisi kelas, dengan membina dan memberikan saran positif dan kritik yang membangun kepada guru untuk meningkatkan mutu guru dan mutu pembelajaran.

Populasi guru Sekolah Dasar (SD) di Indonesia saat ini sangat besar. Namun, guru yang berkualitas dan bermutu masih sangat sedikit. Hal ini dapat dibuktikan pada hasil Ujian Kompetensi Guru yang masih sangat rendah. Data Neraca Pendidikan tahun 2016 menunjukkan bahwa nilai UKG guru tingkat nasional adalah 54,33 dan untuk daerah provinsi Jawa Tengah nilai UKG untuk guru SD adalah 61,88 (Kementerian Pendidikan dan Kebudayaan, 2017). 
Hasil studi pendahuluan di salah satu Sekolah Dasar di Kabupaten Semarang menunjukkan proses pembelajaran yang dilakukan guru terkadang tidak sesuai dengan yang direncanakan dalam Rencana Pelaksanaan Pembelajaran (RPP). Hal ini berarti guru hanya membuat RPP sebagai syarat administratif, bukan sebagai panduan pelaksanaan pembelajaran. Selain itu, dalam proses pembelajaran metode yang digunakan guru tidak bervariasi dan dominan menggunkan metode ceramah. Jika, guru terus melaksanan pembelajaran dengan cara seperti itu maka mutu pembelajaran dan mutu guru tidak akan meningkat, melainkan akan semakin rendah dari itu peneliti ingin menerapkan supervisi akademik untuk meningkatkan mutu pembelajaran dan mutu guru.

Berdasarkan masalah tersebut peneliti melakukan penelitian tindakan sekolah di Sekolah Dasar tersebut dengan tindakan Supervisi Akademik oleh Kepala Sekolah utuk meningkatkan mutu guru. Hasil penelitian ini diharapkan dapat memberikan sumbangan refernsi dalam pengembangan penelitian tindakan sekolah supervisi akademik dalam rangka meningkatkan mutu pembelajaran dan mutu guru. Secara praktis, dapat menjadi umpan balik bagi Kepala Sekolah untuk melaksanakan supervisi akademik secara terprogram dan terstruktur untuk meningkatkan mutu pembelajaran dan mutu guru.

\section{Metode Penelitian}

Penelitian ini merupakan Penelitian Tindakan Sekolah (PTS). Penelitian Tindakan merupakan cara ilmiah yang sistematis dan bersifat siklus yang digunakan untuk mengkaji situasi sosial, memahami permasalahan, dan selanjutnya menemukan pengetahuan yang berupa tindakan untuk memperbaiki situasi sosial (Sugiyono, 2015). Langkah-langkah penelitian yang akan dilakukan adalah (1) membuat perencanaan dengan mempersiapkan instrumen supervisi akademik, (2) melakukan tindakan sesuai dengan langkah-langkah supervisi akademik, (3) melakukan pengamatan berda- sarkan hasil tindakan, dan kemudian dari hasil pengamatan dapat direfleksikan mengenai hasil tindakan dan keputusan untuk melakukan tindakan siklus kedua.

Subjek penelitian adalah tiga orang guru di salah satu Sekolah Dasar di Kabupaten Semarang, Jawa Tengah. Pengumpulan data menggunakan teknik wawancara, studi dokumen Rencana Pelaksanaan Pembelajaran dan observasi pelaksanaan pembelajaran di kelas. Analisis data dalam penelitianini dilakukan secara deskriptif kuantitatif. Penilaian hasil supervisi dihitung pada pra siklus, siklus 1, dan siklus 2 dengan menggunakan rumus dan klasifikasi berikut:

$$
\text { Nilai }=\frac{\text { Total Skor }}{\text { Skor Maksimal }} \times 100
$$

Tabel 1. Klasifikasi Penilaian Supervisi Akademik

\begin{tabular}{ccc}
\hline Interval Nilai & Kualifikasi & Keterangan \\
\hline $86-100$ & $\mathrm{~A}$ & Amat baik \\
$70-85$ & $\mathrm{~B}$ & Baik \\
$55-69$ & $\mathrm{C}$ & Cukup \\
$45-54$ & $\mathrm{D}$ & Kurang \\
$<45$ & $\mathrm{E}$ & Sangat Kurang \\
\hline
\end{tabular}

\section{Hasil Penelitian dan Pembahasa}

\section{Hasil Penelitian}

Pada pra siklus, guru 1 memperoleh skor 56 untuk perencanaan dan skor 60 untuk pelaksanaan, hal ini berarti kualifikasi guru 1 berada pada kategori cukup. Guru 2 memperoleh skor 60 untuk perencanaan dan skor 57 untuk pelaksanaan, hal ini berarti kualifikasi guru 2 berada pada kategori cu-kup. Guru 3 memperoleh skor 70 untuk pe-rencanaan dan skor 75 untuk pelaksanaan, hal ini berarti kualifikasi guru 3 berada pada kategori baik.

Pada siklus 1, guru 1 memperoleh skor 58 untuk perencanaan dan skor 60 untuk pelaksanaan, hal ini berarti kualifikasi guru 1 berada pada kategori cukup. Guru 2 memperoleh skor 65 untuk perencanaan dan skor 70 untuk pelaksanaan, hal ini berarti kualifikasi guru 2 berada pada kategori cukup pada perencanan dan kategori baik 
pada pelaksanaan. Guru 3 memperoleh skor 73 untuk perencanaan dan skor 80 untuk pelaksanaan, hal ini berarti kualifikasi guru 3 berada pada kategori baik.

Pada siklus 2, guru 1 memperoleh skor 58 untuk perencanaan dan skor 60 untuk pelaksanaan, hal ini berarti kualifikasi guru 1 berada pada kategori cukup. Guru 2 memperoleh skor 65 untuk perencanaan dan skor 70 untuk pelaksanaan, hal ini berarti kualifikasi guru 2 berada pada kategori cukup pada perencanan dan kategori baik pada pelaksanaan. Guru 3 memperoleh skor 73 untuk perencanaan dan skor 80 untuk pelaksanaan, hal ini berarti kualifikasi guru 3 berada pada kategori baik.

Pada siklus 3, guru 1 memperoleh skor 60 untuk perencanaan dan skor 65 untuk pelaksanaan, hal ini berarti kualifikasi guru 1 berada pada kategori cukup. Guru 2 memperoleh skor 65 untuk perencanaan dan skor 72 untuk pelaksanaan, hal ini berarti kualifikasi guru 2 berada pada kategori cukup pada perencanan dan kategori baik pada pelaksanaan. Guru 3 memperoleh skor 73 untuk perencanaan dan skor 83 untuk pelaksanaan, hal ini berarti kualifikasi guru 3 berada pada kategori baik.

Hasil tindakan supervisi akademik tersebut menunjukkan bahwa terjadi peningkatan skor yang diperoleh guru pada aspek perencanaan dan pelaksanaan. Meskipun guru 1 masih berada pada kategori cukup, namun dari pra siklus sampai dengan siklus 2 terus mengalami peningkatan. Hal ini berarti supervisi akademik yang dilakukan Kepala Sekolah dapat dapat meningkatkan mutu pembelajaran dan mutu guru.

Hasil ini dapat dicapai karena adanya kerjasama yang baik antar Kepala Sekolah dan Guru yang disupervisi. Setelah melihat hasil pra siklus yang dinilai sangat rendah, Kepala Sekolah berusaha untuk memperbaiki cara guru merencanakan dan melaksanakan proses pembelajaran dengan cara melakukan pembinaan yang intensif. Kepala Sekolah berdiskusi dengan guru mengenai masalah yang dihadapi guru pada proses perencanaan dan pelaksanaan pembelajaran, yaitu mengenai penyusunan silabus dan RPP, metode dan media pembelajaran yang digunakan serta masalah dalam menghadapi peserta didik yang bermasalah di kelas.

Hasil dari tindakan supervisi yang dilakukan mulai dari tahap pra siklus, siklus 1, dan siklus 2 dijabarkan pada Tabel 2.

\section{Pembahasan}

Para kepala sekolah ingin semua guru mereka menjadi guru yang profesional. Guru yang profesional membuat pekerjaan kepala sekolah lebih mudah. Secara realistis, tidak setiap guru adalah guru yang profesional. Profesionalsime seorang guru membutuhkan waktu untuk berkembang. Komponen utama pekerjaan kepala sekolah adalah meningkatkan kualitas guru.

Seorang kepala sekolah yang bekerja efektif memiliki kemampuan untuk membantu guru mana pun dan membawanya ke tingkat berikutnya. Kepala sekolah yang baik akan membantu guru yang buruk menjadi guru yang efektif, guru yang efektif menjadi guru yang baik, dan guru yang baik menjadi guru yang profesional. Kepala sekolah mengerti bahwa ini adalah proses yang membutuhkan waktu, kesabaran, dan banyak pekerjaan.

Tabel 2. Hasil Supervisi Akademik

\begin{tabular}{cccccccc}
\hline \multirow{2}{*}{ No } & Guru & \multicolumn{2}{c}{ Pra Siklus } & \multicolumn{2}{c}{ Siklus 1 } & \multicolumn{2}{c}{ Siklus 2 } \\
\cline { 2 - 8 } & & Perencanaan & Pelaksanaan & Perencanaan Pelaksanaan & Perencanaan Pelaksanaan \\
\hline 1 & Guru 1 & 56 & 60 & 58 & 60 & 60 & 65 \\
2 & Guru 2 & 60 & 57 & 65 & 70 & 65 & 72 \\
3 & Guru 3 & 70 & 75 & 73 & 80 & 73 & 83 \\
\hline
\end{tabular}


Kepala Sekolah sangat diperlukan untuk membantu memecahkan masalah yang dihadapi guru dalam proses pembelajaran. Menurut Sugiyanti \& Narimo (2016), Kepala Sekolah dapat menyelenggarakan pertemuan kolaboratif bersama guru-guru untuk membahas perbaikan dan peningkatan mutu pembelajaran; metode dan media pembelajaran inovatif yang dapat digunakan guru; dan menyelenggarakan pelatihan tindakan kelas. Selain itu guru-guru dapat melakukan diskusi untuk membahas dan memecahkan masalah bersama melalui tukar pikiran dan saling berbagi informasi. Usaha dan upaya tersebut dapat digunakan sebagai wujud dari pemecahan masalah yang dihadapi guru.

Samsuadi (2015) menyatakan bahwa supervisi akademik yang dilakukan pengawas adalah usaha dalam upaya memperbaiki pengajaran, termasuk menstimulasi, menyeleksi pertumbuhan jabatan dan perkembangan guru-guru serta merevisi tujuan-tujuan pembelajaran, bahan pengajaran, metode, evaluasi dan penilaian pengajaran.

Pengawas dalam hal ini Kepala Sekolah diharapkan dapat membimbing guru dalam menyusun silabus dan RPP; membimbing guru dalam memilih dan menggunakan strategi, metode dan teknik yang digunakan dalam pembelajaran; memantau guru dalam proses pembelajaran; membimbing guru dalam mengembangkan dan menggunakan media pembelajaran dan fasilitas pembelajaran secara efektif dan efisien; dan memotivasi guru untuk terus berusaha meningkatkan kualitas dan semakin menyadari perannya sebagai ujung tombak pendidikan ini.

Kepala sekolah dalam melakukan supervisi akademik, diharapkan untuk mempertimbangkan hal-hal yang menjadi prinsip supervisi akademik yaitu mempertimbangkan hubungan konsultatif, kolegial, tidak hierarkis, melaksanakan manajemen yang demokratis, dan berpusat pada guru, serta dilakukan berdasarkan kebutuhan guru secara profesional (Rahabav, 2016, p. 49).

Sistem supervisi akademik sangat bergantung pada observasi kelas yang dila- kukan oleh kepala sekolah atau pengawas. Supervisi akademik didasarkan pada pengamatan, dan melibatkan pengumpulan data terus menerus menggunakan instrumen pengawasan. Persyaratan untuk instrumen supervisi akademik guru harus memenuhi ukuran atau standar tertentu, yang berarti bahwa supervisi akademik dilakukan sesuai dengan indikator kinerja yang telah ditentukan berdasarkan kriteria kinerja yang diadopsi oleh sekolah untuk menentukan efektivitas kinerja guru.

Supervisi akademik guru yang efektif sangat penting untuk memverifikasi dan mempertahankan pengajaran yang berkualitas tinggi dan untuk memastikan bahwa tujuan pembelajaran tercapai. Supervisi akademik guru akan membantu kepala sekolah dan pengawas untuk menilai kualitas pembelajaran yang dilakukan guru.

Supervisi akademik yang dilakukan oleh kepala sekolah kepada seorang guru adalah bagian penting dari keseluruhan proses kinerja guru yang bersangkutan, karena hasil yang diperoleh dari kegiatan pengawasan menjadi dasar bagi pengembangan guru profesional yang berkelanjutan. Pendekatan yang berarti untuk mengevaluasi supervisi akademik adalah alat yang tak ternilai bagi kepala sekolah, pengawas dan guru sendiri untuk mengatasi kebutuhan guru dalam pembelajaran dan untuk menembangkan profesionalisme (Moss, 2015, p. 40).

Supervisi berarti mengawasi pekerjaan yang dilakukan oleh guru sebagai pengajar dan pendidik. Supervisi meningkatkan situasi kegiatan belajar mengajar secara total. Kepala Sekolah harus mengikuti prinsip-prinsip supervisi yang benar yaitu (1) tujuan supervisi untuk membantu, mendorong, dan membimbing bukan untuk mengkritik; (2) ini harus dilakukan dalam semangat kerjasama antara guru dan kepal sekolah; (3) kegiatan supervisi Ini harus dilakukan secara teratur dan efektif; (4) partialitas dan prasangka dalam supervisi; (5) kriteria penilaian harus diketahui guru. Supervisi saat proses pembelajaran di kelas merupakan proses yang sangat penting da- 
lam supervisi. Kelas adalah jantung dari situasi kegiatan belajar dan mengajar

Kunjungan kelas merupakan bagian penting dari tugas Kepala Sekolah. Tapi itu saja tidak memberinya hak untuk menghina atau mengkritik kehadiran seorang guru di kelas. Jika Kepala Sekolah merasa guru tertentu perlu diperbaiki, ia harus melakukannya dengan mengundang guru tersebut untuk berdiskusi secara empat mata, setelah kegiatan supervisi kunjungan kelas. Tugas kepala sekolah adalah untuk meningkatkan kualitas pendidikan melalui kegiatan supervisi yang kreatif, kooperatif dan konstruktif.

Dibutuhkan banyak waktu untuk melakukan supervisi akademik terhadap guru secara menyeluruh. Para kepala sekolah sering kali kewalahan dengan semua tugas mereka. Namun, supervisi adalah aspek yang paling penting ketika meningkatkan kualitas guru. Seorang kepala sekolah harus secara rutin mengamati dan mengawasi ruang kelas guru untuk mengidentifikasi bidang kebutuhan dan kelemahan sehingga dapat membuat rencana individu untuk guru itu untuk meningkatkan profesionalismenya.

Supervisi harus menyeluruh, terutama bagi para guru yang telah diidentifikasi membutuhkan perbaikan yang signifikan. Perbaikan harus dibuat setelah sejumlah besar pengamatan yang memungkinkan seorang kepala sekolah untuk melihat seluruh gambaran tentang apa yang dilakukan seorang guru di kelas. Supervisi ini harus mengarahkan rencana kepala sekolah tentang sumber daya, saran, dan pengembangan profesional yang diperlukan untuk meningkatkan kualitas guru secara individu.

Sesuai dengan tujuan supervisi akademik guru harus mampu menciptakan situasi belajar yang kondusif, mampu untuk mengelola kelas, dan menguasai materi pelajaran. Melalui supervisi akademik guru dapat mempelajari dan memahami tugas dan perannya sebagai seorang pendidik. Guru memegang peranan penting dalam meningkatkan mutu pendidikan. Saat ini diperlukan guru-guru yang mampu melaksanakan tugas dan peran secara profesional untuk menghasilkan sumber daya manusia yang berkualitas.

Direktorat Tenaga Kependidikan (2008) dalam modul Penilaian Kinerja Guru menyatakan bahwa, standar kinerja guru berhubungan dengan kualitas guru dalam menjalankan tugasnya seperti: (1) bekerja dengan siswa secara individual, (2) persiapan dan perencanaan pembelajaran, (3) pendayagunaan media pembelajaran, (4) melibatkan siswa dalam berbagai pengalaman belajar, dan (5) kepemimpinan yang aktif dari guru. Kinerja guru dalam proses belajar mengajar mengacu kepada dimensi tugas utama guru yang meliputi kegiatan merencanakan, melaksanakan kegiatan pembelajaran, dan mengevaluasi hasil belajar siswa, termasuk di dalamnya menganalisis hasil penilaian dan melaksanakan tindak lanjut hasil penilaian.

Hal ini sesuai dengan amanat Undang-Undang Nomor 14 Tahun 2005 tentang Guru dan Dosen Pasal 20 (Presiden Republik Indonesia, 2005) yang menyatakan bahwa kewajiban guru adalah melakukan perencanaan pembelajaran, melakukan pelaksanaan pembelajaran serta melaksanakan penilaian hasil pembelajaran untuk meningkatkan efisiensi dan efektivitas ketercapaian kompetensi lulusan.

Perencanaan pembelajaran adalah sesuatu yang guru harus persiapkan secara sistematis dalam pelaksanaan pembelajaran yang akan dilakukan di kelas bersama siswa (Nadlir, 2013, p. 342). Tujuannya agar kegiatan belajar dapat berjalan secara efektif dan efisien, yang merupakan tujuan akhir yang diharapkan oleh siswa. Umumnya persiapan awal yang dilakukan oleh guru adalah membuat formulasi tujuan pembelajaran yang ingin dicapai pada setiap akhir kegiatan pembelajaran. Tujuan pembelajaran digunakan sebagai tolok ukur dalam menentukan langkah selanjutnya, yaitu serangkaian kegiatan yang akan dilakukan selama kegiatan pembelajaran berlangsung (Siregar, 2013, p. 39).

Setiap guru harus menyiapkan rencana pembelajaran sebelum melakukan kegiatan belajar mengajar. Perencanaan pembelajaran adalah persiapan guru untuk setiap 
pertemuan dan berfungsi sebagai referensi untuk implementasi proses belajar yang efisien dan efektif di kelas. Padahal dalam kegiatan inti guru harus melakukan kegiatan yang merupakan prosesmencapai kompetensi dasar yang telah dimiliki dijelaskan dalam indikator pencapaian dan tujuan pembelajaran. Kegiatan ini dilakukan secara interaktif, menginspirasi, menyenangkan, menantang, memotivasi siswa untuk berpartisipasi aktif, dan menyediakan ruang yang cukup untuk inisiatif, kreativitas dan kemandirian siswa sesuai dengan bakat, minat dan fisik dan pengembangan psikologis siswa. Kegiatan inti menggunakan metode yang disesuaikan dengan karakteristik siswa dan mata pelajaran (Irawan, Wahyudin, \& Yanto, 2018)..

Berdasarkan pernyataan- pernyataan di atas perencanaan pembelajaran merupakan proses persiapan sistematis yang dilakukan oleh guru sebelum pelaksanaan pembelajaran dilakukan. Dalam proses perencanaan, guru menyiapkan materi pembelajaran, perumusan tujuan pembelajaran yang ingin dicapai pada akhir pembelajaran, media pembelajaran, pendekatan, strategi, model dan metode pembelajaran, dan teknik penilaian pembelajaran. Hal-hal ini dirangkum dalam Rencana Pelaksanaan Pembelajaran (RPP) yang disiapkan oleh guru sesuai dengan kurikulum yang berlaku.

Implementasi pembelajaran adalah suatu proses yang berhubungan dengan perencanaan pembelajaran atau dengan kata lain implementasi pembelajaran adalah suatu bentuk operasional perencanaan pembelajaran (Palupi, 2013, pp. 72-73). Sehingga implementasi pembelajaran tidak lepas dari perencanaan pembelajaran yang telah dibuat sesuai dengan kurikulum yang berla$\mathrm{ku}$. Implementasi pembelajaran adalah interaksi antara guru, siswa, materi pembelajaran, sumber belajar dan metode pembelajaran yang terdiri dari kegiatan pendahuluan, kegiatan inti, dan kegiatan penutupan.

Implementasi atau pelaksanaan pembelajaran sesuai dengan kurikulum saat ini di Indonesia, yaitu implementasi pembelajaran menggunakan pendekatan saintifik yang meliputi $5 \mathrm{M}$, yaitu menanya, mengamati, mengumpulkan informasi, mangasosiasikan, dan mengkomunikasikan (Mardiana \& Sumiyatun, 2017, p. 46). Beberapa prinsip pendekatan ilmiah dalam kegiatan pembelajaran adalah: (1) pembelajaran yang berpusat pada siswa; (2) bentuk pembelajaran; (3) belajar menghindari verbalisme; (4) belajar memberikan kesempatan bagi siswa untuk berasimilasi dan mengakomodasi konsep, hukum, dan prinsip; (5) belajar mendorong peningkatan keterampilan berpikir siswa; (6) belajar meningkatkan motivasi belajar siswa dan motivasi mengajar guru; (7) memberikan kesempatan bagi siswa untuk mempraktikkan keterampilan dalam komunikasi; dan (8) proses validasi konsep, hukum, dan prinsip yang dibangun oleh siswa dalam struktur kognitif mereka (Ayuni, 2015). Prinsip pendekatan pembelajaran adalah apa yang di-tuntut oleh guru dalam melaksanakan ke-giatan belajar yang menggunakan Kurikulum 2013.

Evaluasi atau penilaian hasil belajar adalah berbagai kegiatan guru untuk mengolah informasi tentang kemajuan belajar yang dicapai oleh siswa (Herlambang, 2013, p. 148). Penilaian hasil belajar oleh guru berfungsi untuk memantau kemajuan belajar, memantau hasil belajar, dan mendeteksi kebutuhan untuk peningkatan hasil belajar siswa secara berkelanjutan dan berkelanjutan. Penilaian hasil belajar guru dilakukan untuk memenuhi fungsi formatif dan sumatif dalam penilaian, dan bertujuan untuk: (1) menentukan tingkat penguasaan kompetensi, (2) membangun penguasaan kompetensi penguasaan, (3) membangun program peningkatan atau pengayaan berdasarkan pada tingkat penguasaan kompetensi dan, (4) meningkatkan implementasi pembelajaran (Direktur Jenderal Pendidikan Dasar dan Menengah, 2015).

Sehingga dapat dipahami bahwa penilaian hasil belajar yang dilakukan oleh guru adalah proses pengumpulan informasi /data prestasi belajar siswa dalam aspek sikap, aspek pengetahuan, dan aspek keterampilan yang dilakukan secara terencana dan sistematis, untuk memantau proses, kemajuan pembelajaran, dan peningkatan 
hasil pembelajaran melalui penugasan dan evaluasi hasil pembelajaran sesuai dengan kurikulum yang berlaku.

Penilaian pembelajaran untuk Kurikulum 2013 yang berlaku di Indonesia saat ini adalah penilaian implementasi pembelajaran menggunakan pendekatan penilaian otentik yang menilai kesiapan, proses, dan hasil belajar siswa secara keseluruhan. Penilaian otentik dalam Kurikulum 2013 mengacu pada Permendikbud Nomor 66 tahun 2013 tentang Standar Penilaian Pendidikan (Kementerian Pendidikan dan Kebudayaan Republik Indonesia, 2013). Tujuan penilaian otentik, yaitu (1) merencanakan penilaian siswa sesuai dengan kompetensi yang ingin dicapai dan berdasarkan prinsip penilaian, (2) pelaksanaan penilaian siswa secara profesional, terbuka, edukatif, efektif, efisien, dan sesuai dengan konteks sosial budaya; dan (3) melaporkan hasil evaluasi siswa secara objektif, akuntabel, dan informal. Ini adalah pendekatan penilaian yang diperlukan dalam guru untuk menyusun dan melakukan kegiatan penilaian yang menggunakan kurikulum.

Begitu pentingnya supervisi akademik bagi guru maka sekolah perlu dikembangkan kerangka kerja atau instrumen untuk supervisi akademik yang didasarkan pada praktik terbaik yang didukung penelitian, konsisten dalam penerapan, adil bagi guru dan evaluator, dan ukuran kinerja guru yang valid dan dapat diandalkan.

Instrumen tersebut harus mencakup berbagai ukuran kinerja, termasuk tetapi tidak terbatas pada langkah-langkah input seperti bukti pengetahuan guru tentang materi pelajaran; keterampilan dalam merencanakan, menyampaikan, memantau, dan menilai pembelajaran siswa; keterampilan dalam mengembangkan dan memelihara hubungan positif dengan siswa, orang tua, dan kolega; pengetahuan dan keterampilan dalam metode pedagogis untuk memenuhi kebutuhan siswa dengan berbagai gaya dan kebutuhan belajar; dan komitmen terhadap pembelajaran siswa untuk potensi terbaik mereka.

Contoh data hasil supervisi akademik yang juga sesuai dan perlu untuk menilai efektivitas guru adalah pertumbuhan dan kemajuan setiap individu siswa yang diukur pada instrumen standar yang valid dan dapat diandalkan, tes yang selaras dengan kurikulum, demonstrasi kinerja siswa di berbagai media, dan portofolio pekerjaan siswa.

Kepala sekolah harus membuat sistem penilaian kinerja dengan pendekatan berbeda untuk evaluasi yang didasarkan pada pengetahuan, keterampilan, dan pengalaman guru. Misalnya, guru pemula mungkin memerlukan pengawasan yang lebih intensif dalam proses evaluasi.

Selain itu, kepala sekolah harus memberikan umpan balik berupa daftar yang menyertakan kelemahan yang di temukan selama supervisi. Seorang kepala sekolah juga harus memberikan saran terperinci untuk memandu peningkatan guru. Jika daftar ini sangat komprehensif, maka pilihlah beberapa hal yang Anda yakini paling penting. Setelah itu ditingkatkan ke area yang dianggap efektif, maka Anda dapat beralih ke hal lain. Ini dapat dilakukan baik secara formal maupun informal dan tidak terbatas pada apa yang ada dalam supervisi. Kepala sekolah mungkin melihat sesuatu yang dapat meningkatkan guru pada kunjungan singkat ke ruang kelas. Kepala sekolah dapat menawarkan umpan balik konstruktif yang dimaksudkan untuk mengatasi masalah yang lebih kecil.

Kepala sekolah diharapkan dapat mengikut sertakan guru dalam kegiatan pengembangan profesional untuk meningkatkan kualitas guru. Penting untuk dicatat bahwa ada banyak peluang pengembangan profesional. Seorang kepala sekolah perlu melihat secara menyeluruh pada pengembangan profesional yang mereka jadwalkan dan menentukan apakah kegiatan tersebut akan memberikan hasil yang diinginkan. Melibatkan pengembangan profesional dapat mendorong perubahan dinamis bagi seorang guru. Ini dapat memotivasi, memberikan ide-ide inovatif dan memberikan perspektif baru dari sumber luar. Ada peluang pengembangan profesional yang mencakup hampir semua kelemahan yang dimiliki guru. Pertumbuhan dan peningkatan yang 
berkelanjutan sangat penting bagi semua guru dan bahkan lebih berharga bagi mereka yang memiliki kesenjangan yang perlu diatasi.

Semua guru membutuhkan alat yang tepat untuk melakukan pekerjaan mereka secara efektif. Para kepala sekolah harus dapat memberi guru sumber daya yang mereka butuhkan. Ini bisa menjadi tantangan karena kita saat ini hidup di era di mana pendanaan pendidikan adalah masalah yang signifikan. Namun, di era internet, ada lebih banyak alat yang tersedia untuk guru daripada sebelumnya. Guru harus diajar untuk menggunakan Internet dan teknologi lainnya sebagai sumber daya pendidikan di kelas mereka. Guru-guru hebat akan menemukan cara untuk mengatasinya masalah mereka. Namun, para kepala sekolah harus melakukan segala yang mereka bisa untuk memberikan guru sumber daya terbaik atau memberikan pengembangan profesional untuk menggunakan sumber daya yang mereka miliki secara efektif.

Bagi guru baru atau belum berpengalaman, kepala sekolah dapat mengarahkan guru senior untuk membantu guru baru tersebut. Guru senior yang hebat dapat memberikan wawasan dan dorongan yang luar biasa kepada seorang guru yang baru atau yang belum berpengalaman. Kepala sekolah harus mengembangkan guru senior yang ingin berbagi praktik terbaik dengan guru lain. Mereka juga harus membangun suasana yang saling percaya dan mendorong di mana mereka dapat berkomunikasi, berkolaborasi, dan berbagi satu sama lain. Para kepala sekolah harus membuat atau menjembatani hubungan mentor di kedua belah pihak. Koneksi mentor yang solid dapat menjadi usaha belajar yang positif bagi guru senior dan guru junior. Interaksi ini paling efektif ketika dilakukan seharihari dan berkelanjutan.

Selain itu bagi guru baru atau yang belum berpengalaman, kepala sekolah harus mendorong para guru untuk membuat jurnal kegiatan belajar mengajar sehari-hari. Membuat jurnal bisa menjadi alat yang ampuh. Jurnal dapat membantu seorang guru tumbuh dan berkembang melalui refleksi. Hal ini dapat membantu guru dalam mengenali kekuatan dan kelemahan masing-masing dengan lebih baik. Saat guru membuat jurnal, hal ini juga bisa menjadi pengingat yang sangat baik mengenai halhal yang berhasil dan hal-hal yang tidak berfungsi dengan baik di kelas selama kegiatan belajar mengajar.

Selanjutnya yang paling penting dari semuanya adalah kepala sekolah harus membangun komunikasi yang baik dengan guru. Mereka harus mendorong guru-guru mereka untuk membahas masalah atau mencari nasihat kapan saja. Mereka harus melibatkan guru mereka dalam dialog dinamis yang berkelanjutan. Dialog ini harus berkesinambungan terutama bagi para guru yang membutuhkan perbaikan. Para kepala sekolah hendaknya membangun hubungan saling percaya dengan guru mereka. Ini penting untuk meningkatkan kualitas guru. Para kepala sekolahyang tidak memiliki hubungan semacam ini dengan guru mereka tidak akan melihat peningkatan dan pengembangan profesionalsime guru. Para kepala sekolah harus menjadi pendengar aktif yang memberikan dorongan, kritik membangun, dan saran bila perlu bagi peningkatan mutu guru, mutu pembelajaran dan mutu pendidikan di sekolah.

Bagi pengawas sekolah disarankan untuk membantu kepala sekolah dalam pengembangan proses penilaian kinerja guru dan instrumen untuk menciptakan rasa kepemilikan dan komitmen terhadap penilaian kinerja yang efektif yang berfokus pada peningkatan pembelajaran siswa. Pengawas harus membangun kerangka penilaian kinerja yang mengakui peningkatan pengajaran sebagai tanggung jawab kolektif kepala sekolah, wakil kepala sekolah, guru pelajaran dan tingkat kelas untuk memperkaya penilaian dan untuk pengembangan profesionalisme.

Saran bagi dinas pendidikan daerah untuk dapat menyediakan pelatihan komprehensif kepada personel yang berkontribusi pada supervisi untuk memastikan supervisi yang efektif dan adil. Selanjutnya dinas pendidikan daerah harus membuat komite yang terdiri dari guru, kepala se- 
kolah, wakil kepala sekolah, dan pengawas sekolah untuk memilih atau mengembangkan instrumen evaluasi yang valid dan dapat diandalkan yang dapat digunakan semua sekolah di wilayah tersebut

Selain itu dinas pendidikan daerah diharapkan dapat mendukung penelitianpenelitian tentang supervisi dan evaluasi kinerja guru yang sedang berlangsung untuk menetapkan validitas dan reliabilitas program supervisi dan evaluasi guru yang komprehensif. Lebih lanjut memeriksa efektivitas dari teknik atau model yang digunakan untuk memberikan nilai tambah dari program supervisi dan evaluasi guru, dan mendukung pelatihan dan pengembangan profesional yang memadai untuk memastikan implementasi model evaluasi tersebut dalam meningkatkan kegiatan pengajaran dan pembelajaran yang bermuara pada peningkatan mutu pendidikan dasar.

\section{Simpulan}

Berdasarkan hasil dan pembahasan penelitian dapat disimpulkan beberapa hasl sebagai berikut. Pertama, hasil tindakan supervisi akademik 3 orang guru pada siklus 1 dan siklus 2 menunjukkan terjadi peningkatan skor pada aspek perencanaan dan pelaksanaan pembelajaran. Kedua, implementasi supervisi akademik dapat meningkatkan mutu pembelajaran dan mutu guru Sekolah Dasar.

Ketiga, Hasil ini dapat dicapai karena adanya kerjasama yang baik antar Kepala Sekolah dan Guru yang disupervisi. Kepala Sekolah berdiskusi dengan guru mengenai masalah yang dihadapi guru pada proses perencanaan dan pelaksanaan pembelajaran. Keempat, supervisi akademik yang dilakukan Kepala Sekolah merupakan usaha untuk memperbaiki pengajaran, termasuk menstimulasi, menyeleksi pertumbuhan jabatan dan perkembangan guru- guru serta merevisi tujuan-tujuan pembelajaran, bahan pengajaran, metode, evaluasi dan penilaian pengajaran. Kelima, supervisi akademik dapat membantu guru untuk mempelajari dan memahami tugas dan perannya sebagai seorang pendidik

\section{Daftar Pustaka}

Ayuni, F. N. (2015). Pemahaman guru terhadap pendekatan saintifik (scientific approach) dalam pembelajaran Geografi. Jurnal Geografi Gea, 15(2). https://doi.org/10.17509/gea.v15i2.3 542

Direktorat Tenaga Kependidikan. (2008). Penilaian kinerja guru. Jakarta: Departemen Pendidikan Nasional.

Direktorat Tenaga Kependidikan. (2010). Supervisi akademik materi pelatihan penguatan kemampuan kepala sekolah. Jakarta: Kementerian Pendidikan Nasional.

Direktur Jenderal Pendidikan Dasar dan Menengah. (2015). Panduan penilaian untuk sekolah menegah atas. Jakarta: Kementerian Pendidikan dan Kebudayaan.

Elliott, K. (2015). Teacher Performance Appraisal: More about Performance or Development? Australian Journal of Teacher Education, 40(40). https:// doi.org/10.14221/ajte.2015v4 On9.6

Herlambang, A. D. (2013). Pelaksanaan pembelajaran teknologi informasi dan komunikasi (TIK) Sma Negeri. Teknologi Dan Kejuruan: Jurnal Teknologi, Kejuruan Dan Pengajarannya, 36(2). https://doi.org/10.17977/tk.v36i2.407 8

Irawan, D., Wahyudin, A., \& Yanto, H. (2018). The moderating influence of the academic supervision of teacher competencies and commitment towards organizational of teacher performance. Educational Management, $7(1), 65-70$

Kementerian Pendidikan dan Kebudayaan. (2017). Neraca pendidikan daerah. Retrieved November 12, 2017, from https://npd.kemdikbud.go.id/?appid $=\mathrm{ukg}$ 
Kementerian Pendidikan dan Kebudayaan Republik Indonesia. Peraturan Menteri Pendidikan dan Kebudayaan Nomor 66 Tahun 2013 tentang Standar Penilaian (2013).

Mardiana, S., \& Sumiyatun, S. (2017). Implementasi Kurikulum 2013 dalam pembelajaran sejarah di Sma Negeri 1 Metro. HISTORIA, 5(1), 45. https://doi.org/10.24127/hj.v5i1.732

Menteri Pendidikan Nasional Republik Indonesia. Peraturan Menteri Pendidikan Nasional Nomor 13 Tahun 2007 tentang Standar Kepala Sekolah/Madrasah (2007).

Moss, J. T. (2015). The Danielsonmodel of teacher evaluation: exploring teacher perceptions concerning its value in shaping and improving instructional practice. Dissertation. Seton Hall University.

Nadlir, M. (2013). Perencanaan pembelajaran berbasis karakter. Jurnal Pendidikan Agama Islam (Journal of Islamic Education Studies), 1(2), 338. https://doi.org/10.15642/jpai.2013.1. 2.338-352

Palupi, R. S. (2013). Pelaksanaan pembelajaran IPS di SMK Nasional Pati. Jurnal Pendidikan Ekonomi IKIP Veteran Semarang, 1(1).

Presiden Republik Indonesia. UndangUndang No. 14 Tahun 2005 tentang Guru dan Dosen (2005). Jakarta.

Putri, N. H., \& Wibowo, U. B. (2018). Pengaruh kinerja kepala sekolah terhadap keberhasilan manajemen berbasis sekolah melalui partisipasi masyarakat di SMP. Jurnal Akuntabilitas Manajemen Pendidikan, 6(1), 45.

https:// doi.org/10.21831/amp.v6i1.9
810

Rahabav, P. (2016). The effectiveness of academic supervision for teachers. Journal of Education and Practice, 7(9). Retrieved from https://www.iiste.org/Journals/inde x.php/JEP/article/view/29620

Samsuadi, S. (2015). Pengaruh supervisi akademik dan kepemimpinan kepala sekolah terhadap disiplin kerja guru. Journal of Educational Science and Technology (EST), 1(2). https://doi.org/10.26858/est.v1i2.151 5

Shabir, M. (2015). Kedudukan guru sebagai pendidik: (tugas dan tanggung jawab, hak dan kewajiban, dan kompetensi guru). Auladuna, 2(2), 221-232.

Siregar, Y. (2013). Kompetensi guru dalam bidang strategi perencanaan dan pembelajaran Matematika. Formatif: Jurnal Ilmiah Pendidikan MIPA, 3(1). Retrieved from https://journal.lppmunindra.ac.id/in dex.php/Formatif/article/view/114

Sugiyanti, S., \& Narimo, S. (2016). Pengelolaan supervisi akademik oleh kepala sekolah di SD Negeri 6 Putatsari Grobogan. Manajemen Pendidikan, 11(1), 75 https:/ / doi.org/10.23917/jmp.v11i1.1 829

Sugiyono. (2015). Metode penelitian manajemen. Bandung: Alfabeta.

Ungin, M. (2013). Studi tentang kualitas tenaga pengajar (guru) pada SMPN 17 Sendawar Kabupaten Kutai Barat. EJournal Ilmu Administrasi Negara, 1(1). Retrieved from https:/ / ejournal.an.fisipunmul.ac.id/site/?p=634 